\title{
Breast Implant-Associated Anaplastic Large Cell Lymphoma
}

National Cancer Institute

\section{Source}

National Cancer Institute. Breast Implant-Associated Anaplastic Large Cell Lymphoma.

NCI Thesaurus. Code C139012.

A rare anaplastic large cell lymphoma that can develop following breast implants. It has been reported in patients with saline-and silicone-filled implants. It usually presents as an accumulation of seroma fluid between the implant and the surrounding fibrous capsule. The median interval from the time of the implant to the development of lymphoma is approximately 10 years. 